\title{
Library Management by Objectives: The Humane Way
}

As library management and administration become more complex in the seventies, management by objectives offers the library director a possible avenue for coping with the ensuing challenges. Theories of management and administration, including systems analysis, planning, organizing, and controlling, all require objectives and full staff participation for successful implementation. These approaches are discussed as they apply to library management and administration as well as to specific areas of library service and personnel problems.

The whole is greater than the sum of the parts. ${ }^{1}$

\begin{abstract}
A

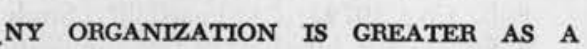
WHOLE than the summation of its services. Yet, the commonality of parts or services, and their integration into an interactive, nonstatic whole, represents a powerful concept when applied to management.
\end{abstract}

The systems, or systems-oriented, approach to either management by objectives or planning, programming, and budgeting systems attempts to assess performance, services, etc., against predetermined goals or objectives. ${ }^{2}$ The systems approach takes a wholistic view of administration and management. Edward $\mathrm{H}$. Litchfield, when examining the major and minor propositions of administration, states that "the administrative process functions in the areas of: A. Policy, B. Resources, C. Execution," and that "the functional areas of administration are integrally related to

Mr. Fields is associate professor, Department of Library and AV Education, St. Cloud State College, St. Cloud, Minnesota. one another." Subsequently, he remarks that "each of the functions is requisite to the total process." "No one entity can be isolated from the other, for they are in fact a continuum of reciprocating parts."4

The whole being greater than the sum of the parts, although a mathematical impossibility, is more meaningful if considered from the viewpoint of an organization. This is pivotal to the library, because its existence depends on service to people, and it is operated by people. Paul Wasserman very aptly reinforces this point when discussing library administration:

Libraries are nothing more than organizations of people enlisted in a common objective. ... What is crucially needed is increased knowledge and understanding of how to accomplish objectives through people. ${ }^{5}$

The summation of the goods and services of an entire staff existing solely for the service of people is somewhat overwhelming in its depth and breadth. The National Advisory Commission on Libraries even extends the concepts of service beyond the usual parameters by 
statung, "Everything the library or librarian does is service." 6 Certainly this statement exemplifies the position that libraries and the management and administration of them are "people" business.

Two basic, but often unrecognized, axioms of management are the universality of managerial functions and the necessary functions, phases, or stages all management must undergo.

1. The fundamental management functions of planning, organizing, motivating, and controlling are applicable to all types of enterprises-hospitals, governments, schools, business, armed forces, and libraries.

2. Managers perform the same functions regardless of their place in the organizational structure or the type of enterprise. The supervisor of pages and the director of libraries each perform the fundamental functions of management. The only differences between them are the differences in objectives, the magnitude of the decisions made, the amount of leadership required, and the complexity of the situations. ${ }^{7}$

Management by objectives as defined here means the identification of objectives within the broad general areas of planning, organizing, controlling, and motivating. A general framework for library management by objectives is proposed here, and explanations as to how this approach is both systematic and humane are offered. It should be noted that each library situation will warrant some modification, but general management techniques and principles are universal in application. Many management situations or environments might identify objectives in planning, yet be totally void of management techniques within each phase in the planning process.

\section{Planning}

A plan or planning phase of any management endeavor can be compared to defining objectives in teaching or preparing research proposals. The plan or planning phase could be called a predetermined course for action. ${ }^{8}$

Lowell, when discussing the various dimensions of preparing a lecture outline on staff objectives, lists the following as aspects important to staff-formulated objectives:

Provide individual motivation to those who must fulfill the objectives

Give direction to the library as a whole

Serve as a basis for delegating and decentralizing work to be done

Coordinate staff work

Provide the basis for control: appraise results in terms of managerial goals and objectives ${ }^{9}$

Each of these reasons for writing objectives has a compelling dimension when considered for management purposes. Key terms of motivation, direction, delegation, decentralization of work, coordination, controlling, and appraisal seem inherently human when examined in terms of an employee-employer relationship. The employee is patently aware of where the organization and he, as a part of the organization, are headed when goals are jointly planned. His position has been defined; he knows where he can go for direction and guidance, who will coordinate the operation, and where controls are applied and evaluations are made.

Formulating objectives by a joint process is most aptly illustrated in the following comments by G. S. Odiorne when defining management by objectives:

The system of management by objectives can be described as a process whereby the superior and subordinate jointly identify goals, define individual major areas of responsibility in terms of results expected of him, and use these measures as guides for operating the unit and assessing the contribution of each of its members. ${ }^{10}$ 
Another view of how management by objectives attempts to involve people at all levels in the objective process, yet keep the parent organization's major objective in focus, is expressed by Ryan:

Management by objectives is a method of leadership which successful executives have been using for generations. It requires the individual executive to develop his own managerial objectives as part of a team striving for a corporate objective agreed and understood by all. It allows the individual executive to accomplish the required results in his own way, so long as this does not interfere with achievement of his own or corporate objectives. In short: you organize your subordinates to help you win your objectives. ${ }^{11}$

Not only should the library have goals and objectives, but it is important for these goals to be compatible with the school, city, or corporation that the library serves. Goals and objectives developed specifically for the library by the parent organization, utilizing both library and nonlibrary staff, seem most likely to succeed, particularly when these goals are for the improvement of the parent organization; i.e., city, college, corporation, school system, or the individual library itself.

Another strong recommendation for library management by objectives is insistence on clear-cut, measurable objectives instead of vague generalizations. In addition, all staff should participate in planning objectives. The following definition of planning by Lowell is an example of how management by objectives can take input from virtually everyone on any staff.

Planning, as a function of management, involves selecting or establishing objectives and goals and implementing them by means of policies, procedures, rules, programs, and strategies. Planning and the responsibility for planning should be engaged in by all supervisors whether they are at the top, the middle, or the bottom of the organization structure. In other words, everyone employed in any kind of supervisory capacity should be concerned with planning, from the director of libraries down to the clerk in charge of after-school pages who do the shelving. ${ }^{12}$

Libraries have the opportunity to develop objectives for management within their planning phases. The opportunity for personnel to know what is expected of them, with whom they will work, and what interactions will take place as they go about their tasks can be communicated through an overall plan, developed and executed by all members of the library staff. The objectives of arranging the general organizational structure can also be written by, communicated to, and participated in by the staff.

\section{Organizing}

Organizing requires developing the plan and successfully implementing its diversity within the organizational structure. Although it requires developing the framework from the planning phase, the organizing phase must have its own defined objectives and a method of measuring its success. Lowell defines organizing as "the framework in which people can work happily, productively, and effectively." 13

Major tenets of organizational structure are to organize personnel, priorities, facilities, responsibilities, and authority in accordance with goals. ${ }^{14}$ Personnel must be aware of the overall objectives of an organization; similarly, they must be aware of the objectives of the specific department and of each major division within the plan. The major advantage for awareness of planning and organization is staff morale. Personnel relegated to technical specialities, uninformed of the overall organizational plan and its receptiveness to their individual input, are victims of a bureau- 
cratic, hierarchical framework.

Although the organizational phase of library management by objectives is practical, there are a number of obstacles. The organizational structure of any library can be weakened by lack of responsiveness to both staff and users. Staff, unaware of library objectives or tied to a bureaucracy which is unresponsive to new input, cannot fully participate in the library's affairs. Libraries with objectives (created by the staff) for the organization phase can respond to staff input; they can also curb some of the bureaucracy lurking at the organization's every orifice.

\section{Controlling}

Another function of management is controlling, which logically follows planning and organizing. Controlling by measuring, comparing, identifying, and analyzing feedback also requires objectives.

Lowell's interpretation of the control phase or stage of management consists of the following five steps:

(1) determining or measuring what is being accomplished,

(2) comparing performance with expected norms or standards,

(3) identifying activities or operations not contributing to the attainment of goals,

(4) locating the reasons for poor achievement, and

(5) taking corrective or remedial action. 15

Problems necessarily arise when measuring quantitative data in the control stage, but these measurements must be made to test and evaluate results. Wasserman, when discussing measurement, comments that "there is no other equally rational criterion for evaluating performance." ${ }^{16} \mathrm{He}$ later states:

Without demonstrable, visible proof of its attainment using an acceptable managerial-type yardstick, the library (this department which defies accounting re- sponsibility because it cannot be subjected to a break-even analysis) becomes an inevitable target of costconscious managements which wield that frightening instrument of internal destruction-the budget-cutting scalpel. ${ }^{17}$

A system of library management by objectives, as defined here, would necessitate an overall plan and specific objectives for the controlling aspect. Some specific recommendations in the form of questions the administration might ask are: How will the data be used for corrective or remedial action? Why was measurement decided upon? How could physical facilities and other portions of the working environment have affected poor achievement? How could the library staff and administration deal with activities or operations not contributing to goals? Finally, how can the entire staff take a long, second look at the original objectives in the planning phase? Perhaps they were unrealistic, or didn't really represent the priorities as they were conceived.

The control phase of any plan for library management by objectives must have a built-in, alternate plan for implementation when the original proves to be faulty. If an alternate plan is impossible or impractical, then the builtin flexibility for redirecting resources must be available.

Measurement of the measurable, once defined, is relatively simplel Measurement of many of the services offered by libraries, however, is extraordinarily difficult. The expeditious achievement of the stated goals of the program is one measure of success and a mark of accountability. ${ }^{18}$ The aspects ascribed to service are difficult to measure and yet vitally important. Some aspects of service are probably impossible to measure accurately at this time, yet they become extremely vulnerable under investigation. 
Wasserman states that perhaps the best solution available for measuring services and qualitative use is to answer the following: "What are the results achieved as compared to the prospects without library services?" The following questions are other measurement techniques which might be applied to the more evasive areas. Are there any written, clear-cut statements about the fundamental goals of the parent organization and the library's relationship to it? Is the person ultimately responsible in the library exerting every overt and covert attempt to operate within and supporting the overall goals, objectives, and philosophy agreed upon by all involved? ${ }^{19}$

\section{Conclusions}

Direct reference to the human dimension of library management by objectives has been limited thus far. The premise that this theory of management is human rests largely in a basic philosophy of man's nature. Many constructs upon which philosophic frameworks are built rest on how man is viewed. Is man inherently passive, active, interactive, good, bad, or neutral? If the good-active or interactive view of man is assumed, then library management by objectives can be considered humane since the total staff is involved in deciding its future.

Douglas M. McGregor, when delineating between an abstract $\mathrm{X}$ and $\mathrm{Y}$ Theory, suggests in Theory $\mathrm{Y}$ that man is not passive or resistant to organizational needs. McGregor maintains that passive resistant behavior is positively rein- forced, whereas personal motivation, development, responsibility, and directive behavior are negatively reinforced. Man has a natural inquisitiveness and motivation; he thrives on responsibility and works toward goals. Management does not give these gifts to man; it needs only to establish an atmosphere wherein these human characteristics can be enhanced and recognized. Management must also provide conditions which not only help people in reaching their own goals but which will also eventually direct their efforts toward the organization's objectives. ${ }^{20}$

Rensis Likert found that, when employees were given job decision freedom and had interaction with their supervisors, production increased. $\mathrm{He}$ also found that the interaction with employees directly motivates them, if the interaction informs employees what is expected of them and if they have a major role in setting their own goals. ${ }^{21}$

Management by objectives for libraries is of paramount importance. Phases of development, planning, organizing, controlling, and measuring are vital. Objectives within each phase or aspect of the organization, combined with the alternatives and the flexibility to incorporate them, are also essential. Total involvement by staff at all levels must be incorporated into any management scheme that intends to be humane and responsive. At a time when major budget cuts loom over almost every facet of public service, accountability is a virtual necessity; the time for a humane system of management by objectives is long overdue.

\section{References}

1. Cecil J. Parker and Raymond A. McGuire, Educational Program: Part Two, No. 5 of Designing Education for the Future, ed. by Edgar L. Morphet and David L. Jesser (New York: Citation Press, 1968), p.63.

2. Steve Knezevich, Management by Objec- tives and Results-A Guide Book for Today's School Executive (Arlington, Va.: American Association of School Administrators, 1973), p.31.

3. Edward H. Litchfield, "Notes on a General Theory of Administration," in Reader in Li- 
brary Administration, ed. by Paul Wasserman and Mary Lee Bundy (Dayton, Ohio: NCR, 1968), p.24.

4. Ibid., p.25.

5. Paul Wasserman, "Development of Administration in Library Services," in Reader in Library Administration, ed. by Paul Wasserman and Mary Lee Bundy (Dayton, Ohio: NCR, 1968), p.39.

6. Douglas M. Knight and E. Shepley Nourse, Libraries at Large (New York: Bowker, 1969), p.166.

7. Mildred $\mathrm{H}$. Lowell, The Management of Libraries and Information Centers (Metuchen, N.J.: Scarecrow, 1968), vol. 2, p.34.

8. Richard A. Johnson, Fremont E. Kast, and James E. Rosenzweig, The Theory and Management of Systems (New York: McGraw-Hill, 1967), p.25.

9. Lowell, Management of Libraries, vol. 2, p.67.

10. George S. Odiorne, Management by Objectives (New York: Pitman, 1965), p.4.
11. Joseph Ryan, "How to MBO," Management Today, April 1971, p. 66-70.

12. Lowell, Management of Libraries, vol. 2, p.37.

13. Ibid., vol. 2 , p.110.

14. Odiorne, Management by Objectives, p.77.

15. Lowell, Management of Libraries, vol. 2, p.184.

16. Paul Wasserman, "Measuring Performance in a Special Library," in Reader in Library Administration, ed. by Paul Wasserman and Mary Lee Bundy (Dayton, Ohio: NCR, 1968), p.74.

17. Ibid., p.174.

18. Ibid., p.175.

19. Ibid., p.178.

20. Douglas M. McGregor, "The Human Side of Enterprise," in Reader in Library Administration, ed. by Paul Wasserman and Mary Lee Bundy (Dayton, Ohio: NCR, 1968), p.214.

21. Rensis Likert, New Patterns of Management (New York: McGraw-Hill, 1961), p.22-25. 